\title{
The Milk of Human Kindness: Curbing Almajiri Vulnerability through Vocational Skill Training in Construction Crafts
}

\author{
Mohammed Adamu Auta ${ }^{1}$ \\ ${ }^{1}$ Department of Technology and Vocational Education, Nnamdi Azikiwe University, Awka, \\ Nigeria \\ Email:ma.auta@unizik.edu.ng
}

DOI: $10.53103 /$ cjess.v1i1.8

\begin{abstract}
Almajiri is a name given to a youthful emigrant purported to be in search of Islamic scholarship. Considering the nature of the Almajiris and their life style, they are people who are in need of assistance to reinvent them and live a productive life. This study explores ways which Almajiris vulnerability can be curbed through vocational skill training in construction crafts. A qualitative study of 24 TVET lecturers drawn from six universities spread across Northern Nigeria where the Almajiris exist. Thematic analysis was used to analyze the data obtained through the interview which lead to the emergence of three dominant issues that could be adopted to curb the vulnerability of Almajir through vocational skill training in construction crafts- Societal reorientation, Stakeholders collaboration, Training, incentive and empowerment. An implication for future research on the Almajiri system both in Nigeria and in other African countries where the system is being practiced was also highlighted.
\end{abstract}

Keywords: Almajiri, Vocational, Skill, Training, Construction, Crafts

\section{Introduction}

Almuhajir is an Arabic word that describes an emigrant- an individual who for one reason or the other moved from his place of birth to another place. There are many reasons why individuals migrate from one location to another, while some emigrate in search of greener pasture; others emigrate in search of peace and tranquility. In the realm of Islamic practices however, Al-shaqiti (2020) identified from the holy Qur'an five reasons why it is necessary for a Muslim to seek for hijra: (1) To abstain from what Allah has forbidden (2) To move from the abode of unbelief to that of believers as witnessed during the Prophet Muhammad's hijra from Makkah to Madinah. (3) For being expelled from your homes. (4) To move away from a place where inequities are being committed and it appears nothing could be done to bring such inequities to an end. (5) The hijra of a sinner when he sins. It can therefore be seen that; the term has evolved over time to the extent that it has deviate from the original norm.

In Nigeria, the word Almuhajir, is pronounced as Almajiri (singular) and Almajirai (plural) which is a name given to (a) juvenile emigrant(s) purported to be in search of 
Islamic scholarship particularly in the area of Qur'an. Abdulfatah (1998) described Almajiri as a Muslim child who is sent out to a place that is far from his home presumably to learn how to recite the Qur' an under the guidance of a Mallam but usually found in a ragged clothes with dry, cracked skin, tattered looks, and appeared unclean and filthy roaming the streets and chanting rhyme, begging and begging with bowl in hand, and who can sleep wherever he found himself usually on the street both in the day and at night. That is to say, they are categories of young people whose parents have decided to abdicate from their parental responsibilities by transferring same to a Mallam without making adequate provision for their upkeep while their Qur'anic studies last.

The history of Almajiri practice can be traced to the Islamic culture and religious life of northern Nigeria prior to the coming of the colonial masters to West Africa (Aliyu, 2014). The teaching of Qur' an and hadith was the complete way of life in Northern Nigeria which had significant influence in the mode of governance, tradition, crafts, trades and even the way one dresses (Abdulqadir, 2003). The activities of the Magribite and Shanqitite who emerged from the north Africa and pass through northern Nigeria on their way to perform pilgrimage at Makkah and the indigenous northern Nigeria Muslims such as Muhammad Al-Amin El-Kanemi who were privileged to have attended Al-Azhar University contributed significantly to the elevation of the indigenous Islamic scholarship (Maigari, 2017).

In the beginning, most of the traditional Almajiri schools received support from the traditional institutions under the leadership of the Emirs; however, with the invasion of the northern region by the colonial masters, Abdulkqadir (2003) reported that the Emirs lost the control of the Almajiri system and that led to the abolition by the colonialist the grants usually extended to the Mallams for the smooth running of the Almajiri schools. Having lost support from the government and perhaps the immediate community, the Almajiri system collapsed paving way for the government funded western education system popularly known as Makarantan Boko in the northern part of Nigeria. Consequently, the pupils metamorphosed to what is now known as Almajiri.

As the system evolved over time, the Qur'anic (Almajiri) school split into twoSlate School and Tsangaya School (Maigari, 2017). The Slate school is designed for the children both male and female from the age of five where they enrolled to learn how to recite the holy Qur'an as inscribed on a slate. This type of school can be found across the length and breadth of the northern Nigerian communities. As a means of survival, the Mallam is usually paid "kudin sati", a weekly due, by the parents whose children are enrolled into the slate school. The children attend such schools from their parents' houses as day students; in fact, it's difficult to find a Muslim, male or female from the northern Nigeria who has not attended such school. However, recent event shows that most of the members of the educated class in the society are not favourably disposed to the idea of taking their children to such schools; rather, they prefer to hire a Mallam for home services. 
The Tsangaya School is one in which the students learn not just how to recite Qur'an, but how to memorize the sixty chapters of the holy book in addition to other book on Islamic jurisprudence such as hadith, fiqh among others. Maigari (2017) reported that, it is an educational institution that has its own physical entity cited either in the outskirt of the town or where it will be completely isolated from the members of the society with scholars' resident within the vicinity. On the average, a Tsangaya school has a student population of about 90 (Isiaka, 2015) depending on the number of Mallams in the employ of the Tsangaya school.

Adetoro (2012) classified Almajiri in the Tsangaya School into three classes: (1) Kolo - these are infants aged between 5 and 15 years. They are the ones who engage in street begging. (2) Titibiri- these are the adolescents aged between 16 and 21. They lead the kolo in street begging and ensure their safe return to the Tsangaya after the days begging session. (3) Gardi- these are adults between the ages of 22 and above who engage in intensive and laborious services to earn a living. That is to say, the population of a typical Tsangaya school is made up of young energetic individuals that have the capacity to engage in any productive venture.

\section{Almajiri and the Abuse of Tsangaya School}

It appears there are no defined criteria for admission into Tsangaya School, the most common practice is having an (un)identified man known as Mallam taking away children mostly from parents who could not cater for the basic needs of their children or from those who failed to move on with the reality of time with regards to modern scholarship. However, a pocket of the parents sent their children to such school based on their firm believe that with the rich contents of the Qur'an, their desire is for their children to learn it so that they can adhere to its teaching in their daily conduct (Idris, 2016). Such group also regards the Mallam as an embodiment of Islamic knowledge who is the most qualified person to mentor their children. As the children grow, they move up the ladder from Kolo to Gardi. Lamenting the pathetic nature of the Almajiri life in Tsangaya School, Taiwo (2013) opined that they care less about the nature of the food they eat since they can pick it from anywhere whether it's fresh, cooked or staled. They rarely take their bath and to the surprise of many, they hardly fall sick.

Recently, a study has shown that deep-rooted extreme poverty and the apparent lack of better alternative are some of the reasons that amplified the Almajiri practice (Hoechner, 2015), and this practice is mostly found among the polygamous, poor and perhaps the uneducated families in northern Nigeria (Perverz, 2005). As things stand, it is apparent that even the Mallams have derailed from the original concept of the Tsangaya School, Maigari (2017) reported Abu-Bakr as saying: 
Some of the teachers have abused these schools especially at the remote areas; they subject the boys into force-labour in their farms. Some of them will deliver the children to the cities and leave them on their own wondering about, these obviously lead to moral perversion and ultimately delinquency the community is then obviously at risk. It is the responsibilities of the authorities to prevent this from happening as much as possible by prescribing a law clearly proclaiming this attitude as illegal and a criminal offence attracting severe punishment on the Mallam.

In an effort to find solution to this problem, the Federal Government of Nigeria (FGN) had earlier made efforts through the soft approach by fusing the Almajiri system together with the western education system so as to see if the plight of street bagging by the Almajiris can be curtailed. That led to the construction of over 100 Almajiri schools spread across the 19 states that made up the northern Nigeria. Unfortunately, Isiaka (2015) reported that the soft approach has not yielded the desired results as the schools were either abandoned by the Mallams or converted to conventional primary schools which led to the continue increase in the number of Almajiris in the recent time.

The hard approach of 'prescribing a law clearly proclaiming this attitude as illegal and a criminal offence attracting severe punishment on the Mallam' which is expected to serve as deterrent to other potential Mallams is a duty exclusively reserved for government at all levels. However, that has not been fully designed and implemented, albeit for political reasons. Even the Child Rights Act which is designed to curb part of these problems has not been domesticated in most of the states of the federation thereby rendering it somewhat ineffective. Even the few states that managed to enact such law have not been implementing them. Therefore, to the best knowledge of the researchers, up to this moment, no Mallam has been apprehended nor prosecuted for forcing the under-aged children into forced-labour.

Considering the fragile security situation in Nigeria, the activities of the Almajiris is becoming a thing of concern. When their activities are left unchecked, there is a tendency that most of them may become potential recruits or have been recruited by bandits and other terrorist groups currently terrorizing the country. Abdullahi (2020) while reinforcing the above assertion noted that:

For several years I observed how hardworking and full of hope and vision most of the Almajiri I encountered were, but I also saw how the hardship and vulnerability they faced made some of them easy recruits for unleashing violence and thuggery. However, overall, in my own personal conviction and from experience, I believe that the majority of Almajirai if given the chance and resources, would be better citizens and follow every norm that deviates from any ugly path of violence or civil unrest. 
Thus, construction industry especially in Nigeria where the menace has reached an alarming proportion have the potentials of making these Almajiris better citizens while still undergoing their Islamic scholarship.

\section{Construction industry and the Increasing Need for Skilled Workforce}

The construction industry all over the world plays a vital role in the socioeconomic development of every nation. It serves as a catalyst for the provision of shelter, infrastructure and employment which are the major indicators of the economic wellbeing of a nation. Park (1989) noted that, the activities of the construction industry provide one of the highest positive multiplier effects to other sectors of the economy through its inherent forward and backward linkages with the other sectors. In Nigeria, the industry has witnessed certain level of growth in the last decade. According to Dantata (2008), the sector is projected to continue to grow very high as long as the price of crude oil which is the major sources of the government revenue remain high and infrastructural development remains on the priority list of the government at all levels. This therefore calls for an increase demand in the number of workforce that will be needed to drive the industry.

Griggs, Eby, Mauoin, Conley, Williamson, Griek and Clauson (2016) opined that, the workforce structure of a construction industry is categorized into skilled labour to unskilled labour. The labour forces under the skilled category include all workers that require some form of professionalism and training outside a university degree. This category of labour force is commonly known as craftsmen; they include bricklayers, plumbers, electricians, tile fitters, carpenters, joiners, iron benders among others. The apprentices who are beginners and interested in learning a specific craft are often categorized under the skilled labour (Giggs et al., 2016).

However, recent events and studies indicated that, there is a sharp decline in the number of skill workforce needed to drive the Nigerian construction industry (Dantata, 2008; Medugu, Majid, Bustani, Bala, \& Umar, 2011; Oseghale, Abiola-Falemu, \& Oseghale, 2015). Most of the industry players relied on workers from the neighbouring countries such as Benin Republic, Togo, Burkina Faso for the sustenance of their firms. The practice of hiring foreigners to take up jobs that ought to be handled by the locals is not only uneconomical, but it has a significant contribution in the skill gap being experience lately and the increasing number of unemployed persons in the country. The question is: How can these Almajiris be exposed to vocational skill training in order to fill the skill gap observed in the construction industry?

Though, Zannah, Latiffi, Raji, Waziri and Mohammed (2017) had warned that the process of recruitment into such crafts needs to be carefully thought-out, as for an individual to venture into a particular craft within the construction industry; certain qualities need to be met. They include Physical strength and stamina, manual dexterity and 
coordination, knowledge and analytical skills, and in-depth knowledge in handling the tools and equipment. While the first three qualities can be assessed prior to the commencement of the apprenticeship, the last will naturally fall in place with adequate training. It can therefore be seen that, the Almajiris in the Tsangaya School who are typically young and energetic can be enrolled into such apprenticeship in order to acquire vocational skills that will enable them play productive roles in the construction industry. This will assist greatly in ameliorating the menace that the Almajiri system has come to be in Nigeria. Based on the literature reviewed, the study therefore, answered the following lone research question:

How can Almajiri vulnerability be curbed through vocational skills training in construction crafts?

\section{Methodology}

\section{Research Design}

The study adopted qualitative research method in order to gain insight into ways in which the Almajiris vulnerability can be curbed through vocational skills training in construction crafts. This approach is relevant to this study since it provides a means of obtaining intricate details about phenomena which may be difficult to obtain using the more conventional method (Strauss \& Corbin, 1998). It also provided an avenue for the participants to express themselves without much restriction thereby providing adequate data that may hitherto not be obtained through the other approaches.

\section{Participants and Sample}

Purposive sampling technique was used to recruit 24 lecturers in all the universities situated in northern Nigeria offering technical and vocational education as participants in this study. The rationale behind this approach is that, this Almajiri menace is more prevalent in the northern part of Nigeria where these universities are domiciled and the areas of specialization of the lecturers constitute the trades obtained in the construction industry.

Questionnaire was sent to the participants through their respective heads of department at the initial stage of the recruitment process, this is to obtain relevant information relative to their years of experience, gender, location, email addresses and phone numbers. The information enabled the researcher to evaluate the suitability or otherwise of the participants in providing the much needed data for the study. A selfaddressed stamped envelope was sent along with the questionnaire for ease of return of the filled questionnaire.

Out of the 31 lecturers who responded to the questionnaire, seven were disqualified 
from participating in the study. The rationale for their disqualification stem from the fact that the seven respondents had less than five years work experience which was set as a prerequisite for participation in the study. The participants were drawn from Yola (8), Bauchi (6), Jos (3), Kano (1), Benue (1), Minna (5) bringing their total number to twentyfour (24). Therefore, only data obtained from the 24 participants was used for the final analysis.

A sample size of 24 is regarded as adequate for a qualitative study of this nature, according to Cresswell (2012) who argues that "it is typical in qualitative research to study a few individuals or a few cases. ... because the overall ability of a researcher to provide an in-depth picture diminishes with the addition of each new individual or site. One objective of qualitative research is to present the complexity of... the information provided by individuals".

\section{Data Collection and Analysis}

Interviews were used for data collection. The rationale for using interview is that, it is one of the most powerful ways in which an individual strive to understand fellow human beings (Fontana \& Frey, 2000). In preparation for the interview, an interview protocol- "a form designed by the researcher that contains the instructions for the process of the interview, the questions to be asked, and space to take note of responses from the interviewee" (Creswell, 2012) was prepared to serve as a guide to the researchers in the conduct of the study.

The selected participants were contacted through the phone numbers and the email addresses they supplied in the questionnaire. The interviews were scheduled at a time that was convenient to the interviewees and was conducted through phone calls and wattsapp calls. As the interview progresses, follow up questions were asked to enable the participants elaborate and clarify certain areas that need further clarifications. Each of the 21 phone interviews and three wattsapp interviews lasted for between 18 to 32 minutes and was audio-recorded using a mobile phone audio-recording feature. This exercise lasted for five weeks.

The audio-taped interviews were manually transcribed verbatim into a written form to facilitate the coding processes and thematic analysis. According to Riessman (1993), the manual transcription processes may appear to be time-consuming, frustrating and even boring; but it provides an excellent means for a researcher to familiarize himself with the data obtained. The interview yielded about 68 transcript pages.

The data obtained as recorded on the transcript pages was coded in line with the following guide given by Braun and Clarke (2006) for thematic analysis: (i) familiarization through writing notes on the text, using highlighters and coloured pens to indicate special patterns. (ii) sorting and classification of codes into themes (iii) collation of all the coded 
data extracts for alignment with the appropriate theme. (iv) reviewing of the coded data extracts for each of the themes to ensure the validity of individual theme relative to the data set to form a coherent pattern. (v) naming of themes in line with the essence of what each theme is about. (vi) writing of the thematic analysis report.

\section{Validity and Reliability}

Member checking was adopted in determining the validity of the findings that emerged from this study. Member checking is the process in which the researcher sought for the opinion of one or more of the study participants to determine the accuracy of the account (Creswell, 2012). In this study, the participants were availed with the findings that emerged from the study and were asked to appraise the accuracy of the report. They were implored to carefully peruse the content and raise any issue they felt was not well or fairly interpreted. At the end of the exercise, no objection was raised thereby reaffirming the validity of the findings.

\section{Findings}

The findings from this study are presented in line with the three themes that emerged from the thematic analysis: (i) societal reorientation (ii) stakeholders' collaboration (iii) training, incentives and empowerment

\section{Societal Reorientation}

The participants acknowledge the existence of the menace that the Almajiri system has grown up to be, and pointed out that societal orientation is the first step that should be taken to ensure that the Almajiris are exposed to vocational skills training in the construction industry and should be pursued vigorously. They confirmed that most of the Mallams may not be favourably disposed to the idea unless concrete efforts are made to enable see the merits behind the initiative. One of the TVE lecturers from Yola explained further:

The Almajiri system has been there even before our grandparents were born. So telling them (The Mallams and perhaps the parents) to restructure it to accommodate some emergent societal norms will naturally face some resistance. But with adequate reorientation, I believe they can make amend and embrace it.

Participants are of the view that successive government have not done enough in making the northern Nigerian society understand and appreciate the evolution that enveloped the country in this century. They may be careless in order to be politically correct, but the damage is taking toll on everyone as elucidated by a TVET Lecturer from 
Minna:

The truth is that, most of the past governments in Nigeria have not done enough in their sensitization drive with respect to this Almajiri phenomenon. I think they have failed to let them know that the system is changing and they need to go with the train. Well, they may be afraid that when they voice it out, it will impact negatively on their political trajectory.

Most of the participants insist that the National Orientation Agency (NOA) which is the body charged with the responsibilities of sensitizing the people about emergent issues in their surroundings have failed woefully in that regards. None of them could recall a time where the agency embarked on any aggressive orientation endeavour towards mitigating the Almajiri menace. A TVET Lecturer from Bauchi explained:

Do we still have NOA (National Orientation Agency)? What are they doing on this Amajiri menace? I can't recall any effort from their angle towards mitigating this problem. They need to wake up from their slumber.

The participants unanimously agreed that both the Mallams and perhaps the parents should be made to see the merit of exposing the Almajiris to some sort of vocational training by utilizing the time they mostly wasted wondering around in search of nonexisting Sadaka to some sort of vocational training perhaps in the construction sites around their immediate environment as succinctly put by a TVET Lecturer from Bauchi:

I wonder why the Mallams and the parents cannot see the need to utilize the time these children go out to scavenge by sending them to these construction sites around so that they can learn may be carpentry, mason work or even iron bending. It will be useful to them in the future. Even in our informal discussions we should make effort to sensitize the Mallams on the need to change from the traditional Almajiri practice because it has outlived its shelve life.

The participants specifically insist that parents should be made to see that they have a duty to cater for the needs of their children, including education. Transferring such divine duties to the Mallam is the highest form of injustice that can be meted on a child. A TVET lecturer from Benue explained:

As parents we are duty bound to cater for all the basic including education need of our children. We should not transfer such burden to anyone because we will be asked to account how we discharged such duties in the hereafter. 
Based on the participant's view, it can be concluded that one of the key areas that needs to be aggressively pursue in order to take off the Almajiris from the street through vocational skills training in the construction industry is the societal reorientation. When the Mallams and the Parents are properly sensitized on the new dynamics that emerged as a result of the societal evolution, they will undoubtedly appreciate the need to make amend in order to fit into the modern ways the society has come to be. This is in agreement with the views expressed by Maigari (2017) on the need for parents to cater for the needs of their children; the author opined that "every father is commanded (by the holy Qur'an) to spend on his family regardless of his financial status, so nobody is pared from this burden. In this regard whoever has the nerve to eject his child at a very tender age and yet claim that he is sending him to learn Qur'an ought to be asked where he gets such precept and wisdom...."

\section{Stakeholders' Collaboration}

Partnership between the Construction industry practitioners, Government, NonGovernmental Organizations (NGOs), Mallams and Parents have been identified by the interviewees as a very important tool that will assist in engaging the Almajiris into vocational skills training in the construction crafts. The participants are of the view that when a strong partnership is established between the stakeholders it will go a long way in smoothing their relationship which will lead to careful planning and execution of the vocational skills training plans. One of the TVET Lecturers from Kano explained:

I have been advocating for partnership between all the stakeholders in the Almajiri project, in fact at every available opportunity, I made it a point of duty to always make my audience realized the need for such partnership. When it is effectively established, it will make the training programme easier to handle. Imagine an Almajiri going to construction site to learn a trade without his Mallams consent! That will be suicidal, because he will naturally be punished by the Gardi or perhaps the Mallam for abandoning his primary role as an Almajiri.

Construction firms were also implored by the participants to imbibe the habit of providing the enabling environment for the Almajiris to excel in their training pursued. In that regards, a TVET Lecturer from Benue said:

My view is that the construction firms through their respective association such as REDA (Real Estate Developers Association) should be made to see the negative implications of the Almajiri practice in its current form and the need to provide a positive response on ways out. Because without their recognition of the need for instance to create an enabling environment 
for the training, I think the outcome may likely be fruitless. So it's a necessary path that should be looked into.

The Cooperation of the mater trainers was also identified as one of the key areas that should be sought and pursued. Being the driving force of the training programme, the master trainers have a key role to play in the actualization of such objectives. Therefore, the Nigerian Association of Engineering Craftsmen (NAEC) should not be left out of the loop. In the view of one of the interviewees who teaches TVET related skills in Jos:

Master Trainers are the key success factors in this endeavour. No matter how hard you try, if the trainers are not fovaourably disposed to do the needful, of course the objectives cannot be achieved. So, we must make effort to see that they are carried along in whatever we intend to perhaps through their associations such as that of engineering craftsmen.

It can therefore be concluded that the collaboration between various stakeholders in the Almajiri project is necessary without which the chances of success of getting these juvenile off the street will continue to narrow down. All the stakeholders have a distinct role to play in the overall success of the Project.

\section{Training, Incentives and Empowerment}

Training is the main thrust of the skill acquisition processes, and therefore it must be vigorously pursued. The participants are of the view that with proper stakeholders' collaboration, instructional supervision albeit informal will be prioritized by those in supervisory capacity within the construction site. By being involved in the programme development, the industry practitioners will be more alert to their responsibilities through provision of the needed resources for the apprentice to excel. A TVET lecturer from Yola put it thus:

Their training must be prioritized. If a little gap is allowed to exist, they may have abandoned the programme and return to the street. We must be very careful not to allow anything that will bring a down time within the training period. Instructional supervision should also be intensified particularly at the early stage of recruitment...

The participants identify adequate incentive as another critical success factor in getting the Almajiris out of the street. According to one of the interviewees who is a TVET Lecturer in Benue, when they are not motivated, they will either abandon the programme or refuse to learn. He put it this way:

The master trainers or the construction firms should at least provide for the trainee (Almajiri) food to eat in order to get the much needed energy 
to work and little stipend as pocket money to solve some of his personal problems. This is in addition to words of encouragement while the apprenticeship last. Otherwise, he may abscond or be there and be doing nothing.

The Mallams also should be offered some incentives by government from time to time since they relied mostly on these Almajiris for their farming activities. With their recruitment into the vocational skills programme, the Mallams may have lost enough labour force his farm and should be assisted generously. A TVET Lecturer from Minna put it this way:

Remember, the Mallams should also be carried long, if you look at it, most of them relied on these guys for their farm work, by the time you take them away, the food security of the Mallam may not be guaranteed. So, government should also look at the other side of the coin as well when making preparation for the programme.

Empowering the Almajiris after their period of training has been identified by the participants as an area that should be given much attention. This is premise on the fact that, the transition from the training programme to the field of work should be done seamlessly in order to avoid the tendency of the Almajiris returning to the streets. According to them:

The transition period should be properly managed through the provision of start-up kits as well as grants for take-off. I can authoritatively tell you that anything short may lead to wasteful effort. Because these guys can return to their Tsangaya School since they have no tools and may be equipment needed to practice their craft. So, we must manage it well.

This therefore highlighted the role that the training, incentives and empowerment will play in taking the Almajiris off the street through the vocational skill training in the construction crafts. It has also highlighted the importance of instructional supervision in all training endeavours which should be encouraged.

\section{Discussion, Conclusion and Implications for Future Studies}

The focus of this study is to identify novel ways on how the Almajiris vulnerability can be curb through vocational skills training in construction crafts. The responses obtain from the participants suggested that societal reorientation, stakeholders' collaboration, training, incentives and empowerment are the major ways in which Almajiris can be taken off the streets through vocational skills training in construction crafts. In summary, the participants were convinced that when the society that practice the Almajiri system is

properly oriented on the menace of the Almajiri system as practiced presently, and all the 
stakeholders in the Almajiri projects established strong collaborate, and the Almajiris adequately trained and motivated through various incentives, and empowered at the end of their training, they will be off the street. These findings are in agreement with the previous studies that favored the importance of inclusivity in vocational skill acquisition (Taiwo, 2013; Kettle, 2015; National Skills Network, 2018; Niehoff, 2018).

According to National Skills Network (2018), skill development is necessary in enhancing employability skills of young people. With special focus on India, the author noted that if skill training is deployed as a strategy towards achieving a specific goal, that can only be made possible through the concerted effort of all the stakeholders- government, industry, social entrepreneurs, NGOs, educational institutions and civil society due to their common aspiration of supporting the cause of skill development. According to Kettl (2015), the most important reason why cross-sectional collaboration is a key to the success of every skills training is that, there is no government that can single-handedly remedy a public problem. Therefore, the authors noted that, establishing collaboration with business, non-profit organizations, and community partners can reduce risks and provide more effective remedies. It will bring together relevant assets relative to knowledge, creativity, financial resources and even transformative capacities for the betterment of the society. Niehoff, (2018) opined that, our communities are populated with experts, professionals, practitioners and leaders in almost all the fields of human endeavour who are readily available to share their expertise on how to move the society forward.

With regards to the training programme, view of Taiwo (2013) opined that the curriculum of any school where the government intends to deploy the Almajiris should be planned to include technical and vocational courses to enable them learn specific crafts so that on graduation they will have something doing instead of returning to the streets. The author also emphasized on the need for aggressive instructional supervision so as to ensure that the right knowledge and skills are being imparted on the students in order to avoid negative indoctrination.

The implication of the findings from this study for practice and policy is that, societal reorientation on the Almajiri menace should be taken with all the seriousness it deserves. All statutory agencies with such mandates should be made to discharge their duties aggressively in order to make both the parents and the Mallams understand the need for the Almajiris to in addition to the normal Qur'anic class acquire vocational skills particularly in the construction craft. Stakeholders collaboration should also be prioritizing while the training, motivation and empowerment of the Almajiris should be put on the concurrent list when drawing up budgets for the project.

One of the major problem facing Nigeria as a country is the issue of insecurity due to the menace of terrorism, banditry, kidnapping, cattle rustling among others; when the Almajiris are allowed to roam the streets without care from the government, they become potential recruits for the enemies of the state (Abdullahi, 2020). This study provided an 
insight into the ways in which the vulnerability of the Almajiri can be curbed through vocational skills acquisition in the construction crafts. One of the strength of this study is that, it adopted qualitative method which enables the researchers to explore and obtained firsthand information through interviews from TVET lecturers/practitioners from across the universities in Northern Nigeria where the Almajiri system is practiced.

However, despite the merits of the methodology adopted in this study there are some weaknesses that are inherent to qualitative research, these includes: the size of the data, scope, reliability among others. Generally, this study provides groundwork for future research on the Almajiri system both in Nigeria and in other African countries where the system is being practiced. These may include development of modules for training of the Almajiris on the various construction crafts obtainable in the construction industry, exploring strategies for effective multi-stakeholder's collaboration on the Almajiris vocational skills training in the construction crafts.

\section{References}

Abdulfatah, M. (1998). The marginalized group in education and national development. Journal of Education, 2(1), 102-111

Abdullahi, A. M. S. (2020). The role of "eTrash2Cash" in curtailing "Almajiri" vulnerability in Nigeria through waste management social microentrepreneurship. In McLean, M. L. (ed.). West African youth challenges and opportunity pathways, gender and cultural studies in Africa and Diaspora. http://doi.10.1007/978-3-030-21092-2_10

Braun, V., \& Clarke, V. (2006). Using thematic analysis in psychology. Qualitative Research in Psychology, 3(2), 77-101. doi: 10.1191/1478088706qp063oa

Creswell, J. W. (2013). Qualitative inquiry and research design: Choosing among five approaches. Thousand Oaks, CA: SAGE.

Dantata, S. (2008). General overview of the Nigerian construction industry. M. Eng. Thesis. Massachusetts Institute of Technology.

Griggs, T. L., Eby, L. T., Mauoin, C. K., Conley, K. M., Williamson, R. L., Griek, O. H., \& Clauson, M. G. (2016). Who are these workers, anyway? Industrial and Organizational Psychology, 9(1), 114-121. doi: 10.1017/iop.2015.123

Hoechner, H. (2015). Porridge, piety and patience: Young Qur'anic students experience of poverty in Nigeria. Africa, 85(2), 269-288. http://doi.org/10.1017/s0001972015000029

Idris, A. (2016). Reductive schooling: A case study of Almajiri integrated model school in northern Nigeria. Current Studies in Comparative Education Science and Technology, 3(1), 145-158.

Kettl, D. F. (2015). The job of government: Interweaving public functions and private hands. Public Administration Review, 75(2), 219-229.

Medugu, N. I., Majid, M. R., Bustani, S. A., Bala, K., \& Umar, A. I. (2011). Craft skills availability in the Nigerian construcytion industry: Perception of contractors and consultants. I U P Journal of Infrastructure, 9(3), 63-69. 
National Skills Network (2018). Is cross-sectional collaboration the key to successful implementation of skill development in India?

http://www.nationalskillsnetwork.in/cross-sector-collaboration-in-skilldevelopment/

Niehoff, M. (2018). 3 ways to model collaboration and partnership in schools and classroom. http://www.gettingsmart.com/2018/02/3-ways-to-modelcollaboration-and-partnership-in-schools-and-classrooms/

Oseghale, B. O., Abiola-Falemu, J. O. and Oseghale, G. E. (2015). An evaluation of skilled labour shortage in selected construction firms in Edo state Nigeria. American Journal of Engineering Research, 4(1), 156-167.

Park, S. H. (1989). Linkages between industry and services and their implications for urban employment generation in developing countries. Journal of Development Economics, 30(2), 359-379

Perverz, T. (2005). Situational analysis of street children in Parkistan. Retrieved from http://www.NCLPA.org

Riessman, C. K. (1993). Narative analysis. CA: Sage

Strauss, A., \& Corbin, J. (1998). Basics of qualitative research: Techniques and procedures for developing grounded theory. CA: Sage

Taiwo, F. J. (2013). Transforming the Almajiri education for the benefit of the Nigerian society. International Letters of Social and Humanistic Science, 19(1), 244-251

Zannah, A. A., Latiffi, A. A., Raji, A. U., Waziri, A. A., \& Mohammed, U. (2017). Causes of low-skilled workers' performance in construction projects. Path of Science, 3(6), 411-415 